\title{
MEMPERKENALKAN SEJARAH PAHLAWAN NASIONAL PAKUBUWONO X BAGI PESERTA DIDIK MI/SD DI INDONESIA
}

\author{
Siti Zulhaida \\ Anis Fuadah Zuhri
}

\author{
UIN Syarif Hidayatullah Jakarta \\ JI. Ir. H. Djuanda No. 95, Cempaka Putih, Ciputat Timur, Tangerang Selatan 15412, Banten, \\ Indonesia \\ zulhaidasiti@gmail.com
}

Naskah masuk: 16-05-20, direvisi: 21-05-20, diterima: 16-05-20, dipublikasi: 30-04-20

\begin{abstract}
Abstrak: Tujuan pembuatan jurnal ini adalah untuk mengetahui: (1) Siapa itu Pakubuwono X; (2) Peran Pakubuwono X dalam sejarah Indonesia; (3) Usaha-usaha apa saja yang dilakukan oleh Pakubuwono $X$ dalam sejarah Indonesia. Jurnal ini ingin membahas tentang Pakubuwono X sebagai Pahlawan Nasional Indonesia. Jurnal ini dibuat menggunakan metode historis. Langkah-langkah yang digunkan dalam metode historis adalah (1) heuristik; (2) kritik; (3) interpretasi; dan (4) historiografi. Teknik pembuatannya dengan mengumpulkan data yang dilakukan melalui studi pustaka. Dalam studi pustaka, penulis berusaha mencari sumbersumber yang relavan dengan tema yang dibahas. Setelah itu data-data tersebut dipelajari dan dianalisa sehingga menjadi sebuah tulisan. Sumber yang digunakan dalam pembuatan jurnal ini adalah sumber tertulis. Pakubuwono $X$ adalah seorang raja pemimpin Kasunan Surakarta yang memerintah pada tahun 1893 sampai dengan 1939. Pakubuwono X merupakan anak dari Sinuhun Pakubuwono IX dan Kanjeng Ratu Pakubuwono. Berdasarkan dari sumber sejarah yang ada bahwa, kondisi politik yang dibangun oleh raja Pakubuwono $X$ terdapat campur tangan oleh pemerintahan kolonial Belanda. Usaha raja Pakubuwono $\mathrm{X}$ dalam pembangunan politik yaitu dengan mendirikan sekolah-sekolah yang salah satunya bernama Mamba'ul Ulum pada tahun 1905.
\end{abstract}

Kata kunci: Pakubuwono X, kepribadian, peran-peran, nilai pendidikan

\begin{abstract}
The purpose of making this journal is to find out: (1) Who is Pakubuwono X; (2) The role of Pakubuwono X in Indonesian history; (3) What efforts were made by Pakubuwono $X$ in Indonesian history. This journal wants to discuss Pakubuwono $X$ as Indonesia's National Hero. This journal was created using the historical method. The steps used in the historical method are (1) heuristics; (2) criticsm; (3) interpretation; and (4) historiography. The making technique is by collecting data which is done through literature study, the author tries to find sources that are relevant to the theme discussed. Afret that the data is studied and analyyzed so that it becomes an article. The sources used in making this journal are written sources. Pakubuwono X was a leader of the Kasunan Surakarta leader who ruled in 1893 until 1939. Pakubuwono X was the son of Sinuhun Pakubuwono IX and Kanjeng Ratu Pakubuwono. Based on historical sources that exist, the political conditions established by King Pakubuwono $X$ interfered by the Dutch colonial government. King Pakubuwono X's efforts in political development were by establishing schools one of which was named Mamba'ul Ulum in 1905.

Keywords: Pakubuwono X, personality, roles, educational values
\end{abstract}

\section{PENDAHULUAN}

Keterampilan tentang menggunakan alat senjata seperti keris, pedang, tombak dan ilmu tentang pancak silat; (4) keolahgaan seperti olahraga renang, dan bermain kuda; (5) ilmu pengetahuan dari buku-buku lama yang diajarkan langsung 
oleh ayahandanya yang terkumpul dalam serat-serat piwulang Jawa; (6) ilmu psikologi atau ilmu tentang kejiwaan; (7) ilmu bahasa seperti bahasa Arab, Melayu dan Belanda (Purwadi, dkk, 2009).

Pada hari Jum'at Legi 28 Ruwah Je 1822 atau $1893 \mathrm{M}$ ayahanda sultan Pakubuwono meninggal dunia. Kemudian ditahun yang sama sultan Pakubuwono $X$ diangkat menjadi raja untuk menggantikan ayahandanya, semalam sebelum upacara pengangkatan raja kepada sultan Pakubuwono $X$ beliau pergi ke masjid Paromosono (yang sekarang disebut dengan Bandengan, yang dahulu letaknya disebelah barat dari Pandopo Parangkarso) dengan pakaian yang serba putih (R.M Karno, 1990). Pemerintah Hindia Belanda menaikkan pangkat sultan Pakubuwono $X$ menjadi Mayor Jenderal. Pemberian pangkat militer secara tituler oleh Belanda kepada raja-raja Jawa sudah ada sejak masa pemerintahan tanpa daerah mancanegara (Purwadadi, dkk, 2007).

Orang-orang menganggap ayanda sultan Pakubuwono $X$ yaitu Sinuhun Buwono IX sebagai guru yang dapat menuntut hidupnya. Selain itu para sesepuh juga sering diajak untuk bertukar pikiran serta bertukar ilmu dengan Sinuhun, seperti Eyangdalem Kusumuyudo ke-II, yang dimakamkan di Lawean, Kiyai Surosemito dan Ngebehi Reksoniti. Sang ayahanda Pakubuwono IX, digambarkan sebagai Prabu Bolodewo, sakti mendoroguno, teteg dan teguh kepribadiannya. Sedangkan sultan Pakubuwono $X$ sendiri digambarkan sebagai Prabu Yudhistira, asih puramarta lahir batin, wicaksono narendrotomo sang Jayeng Katon (R.M Karno, 1990).

\section{METODE}

Dalam kajian ini menggunakan metode studi pustaka. Studi pustaka atau bisa juga disebut dengan pendekatan kepustakaan adalah rangkaian kegiatan yang mencangkup pengumpulan data puskata, membaca, menulis, dan mengelola bahan penelitian.

Teknik pengambilan data tersebut merupakan istilah lain dari kajian pustaka atau tinjauan pustaka. Studi pustaka ini merupakan jenis metode penelitian yang mana penulis tidak harus untuk turun langsung ke lapangan untuk bertemu dengan sumber. Pada metode pustaka ini dapat diperoleh dari data-data yang sesuai dengan perpustakan. Penulis bisa menganalisis tulisannya dengan cara membandingkan karya tulisan orang lain, sehingga penulis memperoleh data-data yang spesifik. Walaupun terlihat mudah, tetapi metode studi pustaka ini perlu sikap ketekunan yang tinggi untuk mencari sumber, membaca, menulis, dan mengolah data-data agar sesuaai dengan tujuan penulisan. Studi pustaka adalah salah satu teknik pengambilan data yang tujuannya untuk memecahkan suatu masalah. Pada dasarnya, teknik ini berpijak kepada penelaahan kritis dan mendalam terhadap bahan atau sumber yang relavan.

Penulis memperoleh referensi dari macam-macam sumber seperti buku, jurnal, artikel, dan karya tulis lainnya. Pada proses penulisan artikel ini, penulis mengumpulkan data-data yang berkaitan dengan tema pembahasan yaitu memperkenalkan sejarah pahlawan nasional Pakubuwono $X$ pada peserta didik Mi/SD. Setelah memiliki sumber-sumber yang memadai, penulis membaca secara mendalam, melakukan analisis dari sumber-sumber terpercaya, dan mendiskusikan tentang hasil informasi yang diperoleh, serta meringkasnya supaya menjadi kesimpulan yang padat.

\section{HASIL DAN PEMBAHASAN}

Penelitian penulisan ini bertujuan untuk memperkenalkan sejarah 
pahlawan nasional Pakubuwono $X$ pada peserta didik Mi/SD. Dengan mengetahui sejarah pahlawan nasional khususnya pahlawan Pakubuwono $X$ kita dapat menambah wawasan mengenai siapa Pakubuwono $X$ itu, apa saja peran-peran yang telah dilakukannya terhadap daerah Surakarta. Selain itu, kita juga dapat mengambil pelajaran dari sikap beliau yang bijaksana dan bertanggung jawab terhadap pemerintahannya.

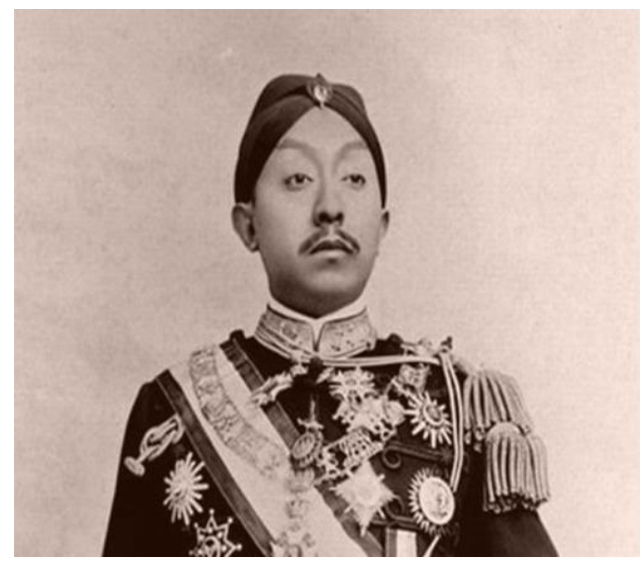

Gambar 1. Pakubuwono X Sumber: Google.com

Banyak orang yang menilai bahwa sultan Pakubuwono $X$ adalah seorang raja yang hanya berkuasa didaerah keraton saja. Meskipun telah menjadi seorang raja, tetapi sultan Pakubuwono $\mathrm{X}$ bukanlah orang yang merdeka sepenuhnya.

Raja memang dipandang tinggi oleh rakyatnya, tetapi sultan Pakubuwono $X$ tidak pernah menjadi orang yang bebas beliau selalu diawasi dan terikat oleh berbagai macam peraturan, sehingga untuk pergi keluar dari keratonnya saja beliau harus meminta izin terlebih dahulu oleh residen. Beliau bagaikan seorang "tawanan" di keratonnta sendiri. Maka tidak aneh jika beliau banyak mengembangkan politik simbolis dari pada politik substantif (Kuntowijoyo, 2014).
Sultan Pakubuwono $X$ adalah seseorang yang mempunyai sifat elusif atau sulit dipahami, membingungkan, dan dianggap sepele oleh para residen dan gubernur yang ditempatkan di Surakarta pada saat masa pemerintahannya. Ada beberapa pejabat yang menilai kepribadian sultan Pakubuwono $X$ sebagaimana diuraikan oleh Residen G.F van Wijk (19091914) dalam George D. Larson (1990) berikut penilaian terhadap sultan Pakubuwono $\mathrm{X}$.

Menurutnya raja ini mempunyai perangai yang sangat lemah. la ingin melakukan sesuatu hal yang menurutnya tepat tetapi ia tidak berani menonjolkan dirinya, karena raja tersebut takut akan terjadinya konflik antar anggota keluarganya atau dengan pegawai-pegawainya di istana. Namun, ada beberapa sifat yang menonjol dari raja ini yaitu sifat kedermawanannya, ia selalu memberikan bantuan dan menyenangkan hati orang lain.

Sultan Pakubuwono $\mathrm{X}$ adalah sosok seseorang yang tidak nampak di dalam dirinya sebuah kewibawaan. Namun, ada desas-desus bahwa sultan Pakubuwono $X$ senang merawat medali-medali yang diperolehnya. Adapun kebenarannya, desasdesus tersebut menunjukkan bahwa adanya ststus yang terlalu berlebihan dari wibawa para Pakubuwono abad ke-20, dan adanya dunia tersembunyi yang terletak dibalik penampilan keagungan seremonial keraton. Sultan Pakubuwono $X$ merupakan seorang yang eksentrik dalam ruang tertutup, yang kosmos kepribadiannya membatasi dirinya sementara kosmos itu juga terbatas, sebagaimana ditunjukkan oleh kisah medalimedali kehormatan itu (John Pemberton, 2003).

Pada dasarnya ada beberapa sifat yang patut ditiru dari sultan Pakubuwono $\mathrm{X}$, di antaranya: 
a. Memiliki kepribadian yang kuat, dalam artian beliau memiliki kedisiplinan yang kuat. Jika beliau menghadapi seseorang yang bertentangan dengan pendirian beliau, maka beliau tidak menghadapinya dengan kekerasan, melainkan dengan sikap yang lemah lembut.

b. Memiliki kemampuan menganalisa yang tajam.

c. Memiliki perasaan yang halus dan tidak suka menyakiti hati orang lain, beliau lebih suka membuat orang lain mrnjadi senang.

d. Memiliki sikap yang terbuka terhadap hal-hal yang baru terutama yang bermanfaat bagi rakyat dan negaranya.

e. Memiliki sikap keadilan yang tinggi. (R.M Karno, 1990)

Kebanyakan orang menganggap bahwa keraton adalah tempat untuk berfoyafoya, makan enak dan bersantai-santai, tetapi anggapan tersebut salah. Sultan Pakubuwono X menjadikan keraton sebagai tempat untuk mendidik dan menggemleng putra-putri, senata dan kerabat keraton. Semua orang yang berada didalam keraton diwajibkan untuk menuntut ilmu baik ilmu kebatinan dan ilmu kewajen juga termasuk dengan ilmu kesenian, agama dan ilmu-ilmu lainnya. Dalam kehidupan sehari-harinya sultan Pakubuwono $X$ tidak pernah mengeluh dan tingkah lakunya tidak pernah berubah (ajeg), beliau sangat disiplin keras, memiliki rasa tanggung jawab yang tinggi dan selalu bersikap keras dan tegas terhadap putra-putrinya tetapi didasari dengan penuh kasih sayang. (R.M Karno, 1990).

Sultan Pakubuwono $X$ hidup sampai dengan usia 72 tahun, menjelang usianya yang ke 33 tahun 1899 beliau mengalami sakit-sakitan karena suka meminum. Namun, dalam usianya yang seperti itu Sultan Pakubuwono $X$ tetap terlihat lebih berwibawa sebagai seorang raja dihadapan rakyatnya. (John Pemberton, 2003).

Sultan Pakubuwono $X$ sangat mementingkan nilai-nilai luhur dan simbolsimbol kebudayaan. Dengan sifat-sifat beliau yang bijaksana dan peran-peran penting yang dilakukannya terutama dibidang pendidikan dan politik, maka inilah yang nantinya akan membawa beliau kedalam peran yang sangat besar dalam usahanya membangun kehidupan politik di daerah Surakarta dan perjalanan Pergerakan Kebangsaan di Surakarta pada abad ke-20.

\section{Peran Pakubuwono $\mathrm{X}$ dalam Landasan Kehidupan Politik}

\section{A. Pendiri Madrasah dan Sekolah}

Diawal abad ke-20 Yogyakarta dan Surakarta dijadikan sebagai tempat daerah otonom yang berdasarkan dengan UndangUndang Desentralisasi tahun 1904. Vorstenlanden adalah bagian dari wilayah Hindia Belanda dan pemerintahannya dibagi menjadi dua keresidenan. Namun, wilayah tersebut memiliki status yang khusus, sebab dua keresidenan tersebut terdiri dari dua kerajaan swapraja yang nominal. Kerajaan semi otonom merupakan suatu bentuk penguasaan dari imperium Mataram yang pernah memerintah pada abad ke-17 dan awal abad ke-18 (George D. Larson, 1990).

Menurut Soemarsaid yang dikutip dari Purwadadi (2009) mengatakan bahwa, "keraton Surakarta yang diperintah oleh sultan Pakubuwono $X$ pada zamannya adalah pusat kebudayaan Jawa yang sudah memberi kontribusi besar terhadap perjalanan panjang sejarah Indonesia. Oleh karena itu, raja atau pemimpin mempunyai kekuasaan yang besar sebagai sumber hukum, pengatur dalam kehidupan bermasyarakat dan bernegara. Berbagai macam bentuk baik politik, sosial, budaya dan keagamaan sangat dipengaruhi oleh 
kebijakan seorang raja atau pemimpin yang berkuasa.

Pada akhir abad ke-20 di Belanda terjadi perubahan politik terhadap Indonesia yakni menjadi Politik Etis yang dipimpin oleh Van Deventer. Hal tersebut terjadi karena adanya pemikiran bahwa Belanda mempunyai hutang budi kepada Indonesia. Politik Etis muncul karena adanya masalah kemanusiaan dan keuntungan ekonomi.

Menurut Wertheim yang dikutip oleh Hermanu. J, (2005) mengatakan bahwa, "Politik Etis pada intinya yaitu pemperluas dan memperbaiki program-program yang telah ada, yakni; perluasan pendidikan model Barat, irigasi, peningkatan program pelayanan kesehatan serta meningkatkan program pertumbuhan industrialisasi".

Sultan Pakubuwono $X$ mampu melihat perubahan dan perkembanganperkembangan baru tersebut serta sadar bahwa generasi-generassi muda harus mampu menjadi orang-orang pintar dan cerdas agar bisa mengimbangi dan bersaing dengan kepintaran orang Belanda hingga suatu saat nanti mampu melepaskan bangsa Indonesia dari penjajahan Belanda. Sultan Pakubuwono $X$ menaruh perhatian besar terhadap pendidikan keagamaan. Sultan Pakubuwono $X$ melaksanakan politik simbolis dengan cara mendirikan sekolah khusus yang digunakan untuk mempelajari agama islam yang dikenal dengan nama "Mamba'ul Ulum" pada tahun 1905. Sekolah itu dibangun dan terletak dibagian selatan halaman masjid besar di Surakarta, yang kini berada diseberang jalan dari pasar Klewer. Lulusan dari sekolah ini dapat diterima menjadi mahasiswa di Universitas Al-Azhar, Kairo dan ada pula beberapa Universitas lain yang berada di luar negeri yang menerima siswa dari lulusan "Mamba'ul Ulum" dengan melalui tambahan kursus dibidang pendidikan.
Kurikulum di sekolah Mamba'ul Ulum dapat ditafsirkan bahwa adanya upaya untuk memadukan antara ilmu pengetahuan agama dan ilmu pengetahuan umum. Menurut Taufik Abdullah yang dikutip oleh Herman J (2005) beliau mengatakan bahwa, "penambahan pelajaran diantaranya bahasa, berhitung, dan ilmu kodrat atau ilmu pengetahuan alam menunjukkan adanya perbedaan dengan pendidikan yang ada dipondok pesantren yang mengutamakan mempelajari kitab-kitab agama islam dan intensifikasi ritual peribadatan". Oleh karena itu, dapat dikatakan bahwa madrasah Mamba'ul Ulum merupakan bentuk transisional menuju pendidikan islami yang modern.

Selain itu, di kampung dan di desa dalam wilayah Kasunanan Surakarta pada tahun 1914 juga didirikan sekolah-sekolah dasar yang diperuntukkan bagi rakyat dan para sentana didirikannya sekolah Kasatrian semacam Hollands Inlandsche School (sekolah yang diperuntukkan kepada orang Indonesia yang diberi nama dengan bahasa Belanda). Didalam Baluwarti, Sekolah Parmadi Siwi (Taman Kanak-kanak/TK) bagi putra dan putri serta cucu-cucu raja dan sekolah "Parmadi Putri" yang hanya diperuntukkan bagi wanita, anak, cucu dan sentana. Sebelum sekolah Parmadi Putri dibuka, para putri raja mendapat pendidikan dalam bahasa Belanda, masak memasak, dan membuat kerajinan tangan seperti, merajut, menyulam, merenda dan lain sebagainya yang diajarkan oleh wanitawanita Belanda di hari-hari tertentu atau bisa dikatakan seperti les (R.M Karno, 1990).

B. Usaha-usaha dalam Bidang Politik Usaha-usaha yang dilakukan oleh sultan Pakubuwono $X$ dalam membangun kehidupan politik di daerah Surakarta menjadi lebih lengkap karena adanya peran beliau dalam membantu dan mengayomi organisasi-organisasi nasional, dalam 
usahanya untuk melawan dan mengusir Belanda dari tanah Jawa. G.P.H Hangabehi dan G.P.H Kusumoyudo pernah menjadi Anggota Kepengurusan Besar Sarekat Islam yang dipimpin oleh R.M HOS Tjokroaminoto sedangkan organisasi Boedi Oetomo dipimpin oleh G.P.H Hadiwidjojo, R.M T Woerjaningrat (yang merupakan keponakan dan menantu dari sultan Pakubuwono $\mathrm{X}$ ) beliau adalah tokoh-tokoh yang terkenal dalam kepengurusan Boedi Oetomo (Purwadadi, dkk, 2009).

Sultan Pakubuwono $X$ sangat menyadari bahwa perwakilan rakyat sebagai salah satu bentuk sarana demokrasi dapat dijadikan sebagai landasan untuk melaksanakan kekuasaan eksekutif pemerintah. Pada tanggal 21 Maret tahun 1935 sultan Pakubuwono X mendirikan "Bale Agung" sebagai lembaga yang memberi pertimbangan dan sebagai perwakilan rakyat sepenuhnya. Dengan adanya Bale Agung, maka Dewan kerajaan yang sebagian besar terdiri dari keluarga raja Pakubuwono $X$ dihapus. Bale Agung terdiri dari satu orang ketua yang ditunjuk langsung oleh sang raja, yakni ketuanya adalah G.P.H Hadiwidjojo dan R.T. Mr. Wironegoro sebagai sekretaris (R.M. Karno, 1990).

C. Perjalanan Politik Buwono

Sultan Pakubuwono dalam strateginya membuat usaha-usaha dengan melakukan perjalanan kerja ke berbagai daerah yang disebut dengan incognito atau Ngideri Buwono (Kuntowijoyo, 2004). Dalam tinjauan islam kata Ngideri Buwono merupakan tindakan diplomatis guna menciptakan strategi pergolakan. Di dalam islam, diplomasi yaitu Kayfiyah (cara atau metode) untuk disampaikan kepada khalayak umum sebagai bagian dari uslub kifahi (strategi pergolakan) guna menghadapi pemerintah Belanda (Muhammad Hawari, 2003).
Dalam menjalankan tugasnya, sultan melakukan perjalanan malam yang mengelilingi kota agar sultan bisa merasakan suka duka dan keluhan dari rakyatnya. Pekerjaan ini merupakan tugas setiap sultan/raja yang berasal dari keturunan Mataram. Pada suatu malam, ketika sultan sedang melakukan tugasnya dalam keadaan gelap beliau harus melompati parit dan tergelincir di kampung Ngruki, daerah Kedawung Barat. Akibatnya kaki sultan Pakubuwono $X$ menjadi cacat, dan tidak dapat disembuhkan sehingga beliau tidak kuat untuk berjalan lama.

Proses perjalanan Ngideri Buwono meliputi perjalanan ke berbagai wilayah seperti Jawa, Sumatera Selatan, Bali dan Lombok dengan menggunakan transportasi berupa kereta api dan kapal laut. Pada awal abad ke-20, pada masa pemerintahan Residen Vogel, sultan Pakubuwono $X$ melakukan perjalanan menuju Semarang dengan membawa dua ratus pengiring. Pada tahun 1916 sultan Pakubuwono X membuat rencana untuk pergi ke Buitenzorf (Bogor) untuk menyampaikan ucapan terimakasih kepada Sri Maharatu Wilhelmina atas pemberian bintang Grootkruis in the Orde van Oranje Nasaau lewat Gubjen De Fock. Kemudian dua tahun berikutnya pada tahun 1924 sultan Pakubuwono X melakukan perjalanan ke Malang. Pada tahun 1929 sultan Pakubuwono $X$ beserta rombongannya mengunjungi pulau Bali dan pulau Lombok.

Saat di pulau Bali Sultan Pakubuwono X mengunjungi I Gusti Gede Bagus Jelatik yang bertempat di Karangasem dan Anak Agung I Gusti Gede Taman di kabupaten Bangli. Selain itu, beliau juga berkunjung ke tempat asisten Residen Mataram (Lombok). Di tahun 1935 sunan Pakubuwono $X$ berkunjung ke Lampung. Ditahun berikutnya yaitu tahun 1936, dengan alasan meninjau Gubernur Surakarta yang 
dirawat di Rumah sakit Surabaya, sunan Pakubuwono $X$ bersama rombongannya pergi ke Surabaya, lalu beliau singgah di kabupaten Gresik (Darsiti Soeratman, 2000).

Sunan Pakubuwono $X$ mendapat kritik dari para pejabat Belanda tentang perjalanan Ngideri Buwononya. Para pejabat Belanda memikirkan masalah uang yang dikeluarkan dan mengenai efek politik dari investasi ini, meskipun sunan Pakubuwono $X$ dianggap mengadakan perjalanan incognito, sehingga beliau menunjukkan dirinya sebagai kaisar Jawa (George D. Larson, 1990). Semua perjalanan yang dilakukan oleh sunan Pakubuwono $X$ merupakan rangka dalam membangun kehidupan politik di Surakarta dan nasionalisme Indonesia melawan penjajahan Belanda.

\section{Peran Keraton dalam Pergerakan Kebangsaan}

1. Kondisi Politik Surakarta pada Masa Pemerintahan Pakubuwono $\mathrm{X}$

Di awal abad ke-20 merupakan periode awal dari bangkitnya pergerakan dan perubahan struktur sosial kemasyarakatan oleh pemerintah kolonial. Kunci dari perkembangan di awal abad ke-20 yaitu munculnya gagasan atau ide-ide baru mengenai organisasi dan dikenal dengan definisi-definisi baru yang lebbih canggih tentang identitas. Gagasan baru tersebut berisi tentang organisasi yang meliputi bentuk-bentuk kepemimpinan yang baru, dan definisi yang baru lebih canggih lagi terutama mengenai identitas seperti analisis yang sifatnya lebih mendalam tentang lingkungan agama, politik serta ekonomi. Di tahun 1927 telah terbentuk suatu organisasi kepemimpinan Indonesia yang baru dan dengan pengorbanan yang sangat besa. Antara pemimpin baru yang satu dengan pemimpin baru lainnya juga terlibat dalam pertentangan yang sangat sengit itu, sedangkan kesadaran yang berada dalam diri mereka masing-masing semakin besar dan telah memecah belah kepemimpinan melalui garis-garis agama dan ideologi. Kemudian pihak kolonial Belanda mulai menjalankan tingkat penindasan barunya sebagai jawaban atas perkembanganperkembangan tersebut. Pada periode ini tidak memecahkan suatu masalah, akan tetapi malah merubah pandangan kepemimpinan Indonesia itu mengenai diri sendiri dan masa depannya (M. C Ricklefs, 1991).

Pada permulaan abad ke-17 sampai dengan abad ke-20 timbullah peperangan dan pemberontakan, peperangan tersebut tidak berhasil karena senjata yang kita miliki jelek dan taktik Belanda lebih bagus sehingga berhasil untuk mengarang barisan Indonesia. Tetapi setelah terjadinya peperangan dan pemberontakan itu habis, kemudian timbullah nasib rakyat yang jelek itu menjadi rasa sedih dan sengsara, yang terkadang keadaan tersebut menjadi berbagai macam aksi yang dibuat oleh rakyat (A.K Pringgodigdo, 1994).

Kemudian pada awal abad ke-20 daerah Surakarta dan Yogyakarta dijadikan sebagai tempat otonom yang berdasarkan pada Undang-Undang Desentralisassi tahun 1903. Wilayah Vorstenlanden adalah bagian dari wilayah Hindia-Belanda serta pemerintahannya dibagi dalam dua keresidenan. Akan tetapi wilayah tersebut mempunyai status yang khusus, sebab kedua keresidenan itu terdiri dari dua kerajaan swapraja yang nominal. Kerajaan semi-otonom ini merupakan suatu proses penguasaan dari impremiun Mataram yang pernah menjadi pemegang kekuasaan pada abad ke-17 dan pada awal abad ke-18 (George D. Larson, 1990).

2. Nilai Sejarah Keraton sebagai Materi Pengembangan bagi Peserta Didik MI/SD

Peristiwa sejarah yang ada di kerajaan Surakarta sangatlah berpengaruh 
dan merupakan kerajaan besar pada masanya. Hal tersebut dapat dilihat dari macam-macam peninggalan sejarah yang tersimpan pada Museum Radyopustoko, Kraton Kanunan, dan Istana Mangkunegaran. Di dalam sejarahnya, pemerintahan Kasunan dan Mangkunegaran disaat masa kejayaannya cukup banyak mewariskan nilai-nilai pedagogis yang dapat dijadikan sebagai materi pengembangan pembelajaran mata pelajaran IPS MI/SD, diantaranya: nilai religius/keagamaan, nilai politik, nilai ekonomi, dan nilai budaya.

a. Nilai Religius/Keagamaan

Nilai religi/keagamaan dari peninggalan keraton Surakarta yang sangat nyata misalnya seperti:

1) Masjid Agung

Dalam bahasa Jawa nama Masjid Agung

Surakarta adalah Masjid Ageng Karaton

Surakarta Hadiningrat. Masjid ini dibangun pada saat pemerintahan sultan Pakubuwono III tahun 1763 dan selesai ditahun 1768 diatas tanah seluas 19.180 meter persegi. Masjid ini termasuk kedalam katagori Majid Jami', yaitu artinya masjid yang dapat dipakai untuk sholat berjamaah dengan jumlah makmum yang banyak terutama ketika sholat Jum'at dan sholat led. Masjid ini merupakan ststus sebagai masjid kerajaan, masjid ini juga digunakan sebagai pendukung seluruh kepentingan kerajaan yang berkaitan dengan acaraacara keagamaan. Semua para pegawai masjid dijadikan sebagai abdi dalam keraton, dengan gelar Kanjeng Raden Tumenggung, Penghulu Tafsiranom untuk penghulu, dan Lurah Muadzin untuk orang yang mengumandangkan adzan.

2) Masjid Mangkunegaran

Masjid Mangkunegaran diprakarsai oleh seorang Kanjeng Gusti Pangeran Adipati Arya Mangkunagara I (Raden Mas Said) di kadipaten panatagama yang memiliki luas lahan sekitar 4.200 meter persegi. Sebelumnya masjid ini terletak di daerah Kauman Pasar Legi, kemudian pada masa pemerintahan Adipati Mangkunagara II dipindahkan ke daerah Banjarsari dengan alasan letaknya yang strategis dan dekat dengan pura Mangkunagaran.

3) Masjid Laweyan

Masjid Lawean ini dibangun pada saat pemerintahan Djoko Tingkir yaitu sekitar tahun 1546 dan termasuk masjid pertama yang ada di Kerajaan Pajang. Pada awalnya masjid ini merupakan bangunan pura agama Hindu. Kemudian dengan adanya pendekatan secara damai, sehingga semakin banyak orang yang memeluk agama islam, maka bangunan pura itu diubah menjadi masjid. Pemilik dari Masjid Laweyan ini adalah Kyai Ageng Henis (yang merupakan kakek dari sunan Pakubuwono II). Masjid Laweyan ini digunakan sebagai tempat sholat, pernikahan, talak, rujuk, musyawarah dan makam. Ditempat makam terdapat sebuah pintu gerbang disebelah samping yang khusus dibuat untuk sunan Pakubuwono $X$ ketika berziarah ke makam.

4) Geredja Katholik Antonius

Gereja ini merupakan gereja tertua yang ada di Surakarta dan didirikan pada tahun 1905. Gereja Katholik Antonius memiliki skala bangunan yang besar dan gereja tersebut belum berubah bentuknya hingga saat ini.

5) Tempat Ibadah Tien Kok Sie Tempat ini merupakan Klenteng yang terdapat di Jalan R.E Martadinata no.12. Pada awalnya Klenteng ini terleak di Kartasura (sebelum Keraton Kartasura dipindahkan ke Surakarta pada tahun 1744). Kemudian Klenteng ini pindah ke Sala dan dibangun bersamaan dengan pembangunan Keraton Surakarta. 
Meskipun Klenteng Tri Dharma merupakan tempat ibadah, tetapi sebutan Klenteng diubah menjadi "Wihara".

6) Vihara Am Po Kian

Vihara Am Po Kian ini didirikan pada tanggal 24 Agustus 1875 kemudian mengalami perbaikan pada tanggal 14 Agustus 1944. Pada awalnya vihara ini merupakan bangunan kuil yang dijadikan sebagai tempat beradu kekuatan ilmu kebatinan. Kemudian vihara ini dapat dikuasai oleh Kyai Ageng Henis dan diubah menjadi sebuah masjid, dan di dalamnya terdapat makam beliau beserta keluarganya.

b. Nilai Politik

Nilai dalam bidang politik dapat dilihat dari banyaknya organisasi-organisasi pergerakan yang mulai muncul menyuarakan aspirasi rakyat pribumi yang hidup dalam penindasan penjajah. Para penjajah ingin menghancurkan kekuasaan yang ada di Indonesia. Kemudian, mulai munculnya paham-paham baru seperti paham nasionalisme, paham liberalisme, paham sosialisme, dan paham demokrasi. Semangat nasionalisme pada masa itu digunakan sebagai paham atau ideologi bagi organisasi pergerakan, yang salah satunya ialah Partai Nasional Indonesia (PNI) yang dipimpin oleh Ir. Soekarno.

Pada masa itu, peninggalan peristiwa sejarah di Surakarta cukup mewarnai kehidupan politik, misalnya seperti yang dilakukan oleh Sultan Agung yang memerintah di tahun 1613-1645 perannya melawan VOC. Selain itu juga terdapat peran-peran sultan Pakubuwono $X$ yang nampak terhadap pemerintah Hindia Belanda. Beliau mampu menjauhkan pertentangan yang cukup serius, bahkan tampil sebagai teman pemerintah Hindia Belanda. Di mata rakyat kewibawaannya semakin meningkat sebagai raja Jawa. Sunan Pakubuwono X sadar, bahwa sebagai cucu Pakubuwono VI, beliau harus meneruskan perjuangan kakeknya dalam mengusir penjajah.

c. Nilai Ekonomi

Kota Surakarta merupakan kota yang strategis dan juga menjadi tempat perlintasan yang menghubungkan pulau Jawa bagian barat dan bagian timur sejak zaman kolonial sampai sekarang ini dan tentunya sangat menguntungkan dalam hal perkembangan ekonomi rakyat. Salah satu bukti nyatanya yaitu yang dilakukan oleh sultan Pakubuwono $\mathrm{X}$, beliau memberikan kredit untuk pembangunan rumah yang ditujukan kepada warga yang kurang mampu. Kemudian, dibangunnya stasiun solo jebres, stasiun solo-kota atau sangkrah, jembatan jurug yang melintasi bangsawan solo di timur kota, dan masih banyak lagi. Untuk membantu perekonomian rakyat pada saat itu, maka terdapat beberapa lembaga perekonomian misalnya seperti, pasar gede, pasar klewer, dan Bank Indonesia.

d. Nilai Budaya

Peninggalan sejarah dalam bidang budaya, Keraton Surakarta telah mewariskan nilai-nilai budaya yang masih tetap dilestarikan oleh masyarakat bahkan hingga saat ini. Nilai-nilai budaya tersebut dapat dilihat di dua istana keraton yakni Istana Keraton Kasunanan dan Istana Keraton Puro Mangkunegaran. Istana Keraton Kasunanan Surakarta Hadiningrat dibangun pada tahun 1744-1746 oleh sultan Pakubuwono II yang terletak di Desa Sala. Setelah pembangunan selesai, nama desa itu diganti menjadi Surakarta Hadiningrat. Istana ini menjadi saksi bisu dalam penyerahan kedaulatan Kerajaan Mataram oleh sultan Pakubuwono II kepada VOC di tahun 1749 dan setelah terjadinya Perjanjian Gayanti di tahun 1755, keraton ini dijadikan istana resmi bagi Kasunanan Surakarta hingga tahun 1946. 
Hal menarik yang terdapat di Keraton Kasunanan adalah adanya patung-patung Eropa yang menghiasi istana sehingga terdapat kombinasi yang indah antara arsitektur Jawa Kuno dengan sentuhan Eropa. Patung-patung tersebut merupakan hadiah pemberian Belanda yang dulu mempunyai hubungan baik dengan Kasunanan Surakarta. Keraton Kasunanan Surakarta merupakan tempat yang mengandung makna spiritual yang tinggi.

Kemudian, pada bagian utara kawasan kota Surakarta yang ditata oleh pihak Istana Mangkunagaran, juga mempunyai jejak arsitektur yang cukup banyak mengandung sentuhan Eropa. Pada bagian utara kota Surakarta yang dilweati oleh kali pepe sering menimbulkan bencana banjir. Oleh karena itu, untuk mengantisipasi hal tersebut, maka dilakukanlah pembangunan tanggul kali dan pintu air, saluran drainasi, dan MCK (mandi cuci kakus). Semua bangunan tersebut masih terlihat sampai sekarang dan merupakan beberapa bukti pembangunan yang dikakukan pada masa pemerintahan Mangkunegoro IV.

Selain bukti peninggalan budaya yang berupa bangunan, ada pula peninggalan budaya yang berupa kesenian. Seperti Gending Kodhok Ngorek. Gending tersebut merupakan salah satu bentuk peninggalan budaya dan seni tradisi Kasunanan Surakarta Hadiningrat, khususnya dibidang seni musik istana. Gamelan dan gending Kodhok Ngorek merupakan sebuah perangkat gamelan Jawa serta nama-nama lagu yang dibunyikan pada waktu dan kesempatan tertentu saja. Lagu-lagu dalam gending kodhok ngorek diberi nama Kalapanganjur. Sebenarnya, gending Kodhok Ngorek sudah dikenal sejak zaman raja-raja terdahulu, misalnya pada masa Kerajaan Mataram Islam, Kerajaan Jenggala, dan lain sebagainya. Gending Kodhok Ngorek sampai sekarang masih tetap dilestarikan oleh empat kerajaan pewaris tahta wangsa Mataram. Seperti Kasunanan Surakarta Hadiningrat, Kerajaan Ngayogyakarta Hadiningrat, Kadipaten Pakualaman, dan Kadipaten Mangkunegaran di Surakarta.

\section{PENUTUP}

Sultan Pakubuwono $\mathrm{X}$ merupakan seorang pemimpin yang mempunyai kepribadian kuat, beliau memiliki sikap disiplin diri dan bijaksana. Usaha-usaha yang dilakukan sultan Pakubuwono $\mathrm{X}$ dalam membangun kehidupan politik di Surakarta dipengaruhi oleh berbagai hal, yaitu dengan keadaan Surakarta yang terdiri atas wilayah Kasunanan dan Mangkunegaran, kedua wilayah tersebut dipisahkan oleh suatu jalan yang besar. Sultan memiliki peran andil yang cukup besar dalam pergerakan organisasiorganisasi kebangsaan di Surakarta. Usaha beliau dalam membangun landasan politik di Surakarta yaitu dengan mendirikan madrasah Mamba'ul Ulum pada tahun 1905 dan sekolah-sekolah lainnya bagi rakyat dan para sentana.

Daerah Keraton Kasunanan Surakarta merupakan daerah yang subur untuk tumbuhnya organisasi-organisasi sosial politik. Beliau bersama-sama dengan rakyat bersatu untuk melawan kekuasaan Belanda, melalui gerakan organisasi Boedi Oetomo atau melalui gerakan perbaikan ekonomi dan sosial politik seperti yang dilakukan oleh organisasi Sarekat Islam. Organisasi Boedi Oetomo merupakan gerakan organisasi priyayi baru, yang memperoleh kedudukan berkat pendidikan Barat yang mereka peroleh, tetapi statusnya tidak dapat diperoleh kerena mereka merupakan keturunan dari keluarga pangreh praja lama. Sedangkan organisasi Sarekat Islam merupakan gerakan nasional pertama yang muncul di Surakarta pada tahun 1912. 
Pada dasarnya, organisasi Sarekat Islam adalah gerakan yang dibangun untuk mengusur kolonial Belanda dan Cina dari tanah Jawa. Tujuan dari didirikannya Sarekat Islam adalah untuk merebut tanah Jawa dari tangan Belanda lewat revolusi, yang kemudian akan diserahkan kembali kepada Susunuhan.

\section{UCAPAN TERIMA KASIH}

Syukur alhamdulillah penulis ucapkan kepada Tuhan Yang Maha Esa karena berkat rahmat dan petunjuk-Nya penulis dapat menyelesaian tugas ini. Tak lupa juga penulis ucapkan kepada guru pembimbing yang selalu memberikan arahan dan motivasi kepada penulis.

\section{REFERENSI}

Abdulghani, R. (1963). Penggunaan IImu Sejarah. Bandung: Prapanca.

D, L. G. (1990). Menjelang Revolusi Keraton dan Kehidupan Politik di Surakarta. Yogyakarta: UGM Pres.

Emulyasa. (2007). Standar Kompetensi dan Sertifikasi Guru. Bandung: PT. Remaja Rosdakarya.

Hawari, M. (2003). Politik Partai.Merentas Jalan Baru Perjuangan Partai Politik Islam. Bogor: Ide Pustaka.

Karno. (1990). Riwayat dan Falsafah Hidup Ingkang Sinuhun Sri Susuhunan Paku buwono $X$. Jakarta.

Karno, K. (1983). Pemimpin dan Kepemimpinan. Jakarta: Raja Grafindo.

Koentjaraningrat. (1986). Metodologi Penelitian Sejarah. Jakarta: Gramedia.

Kuntowijoyo. (2001). Pengantar IImu Sejarah . Jakarta: Yayasan Banteng Wijaya.

Kuntowjoyo. (1995). Metodologi Sejarah. Yogyakarta: Tiara Wacana.

Pemberton, J. (2003). "Jawa" On The Subject Of Java. Terjemahan Hartono Hadikusumo. Yogyakarta: Mata Bangsa.

Pringgodigdo. (1994). Sejarah Pergerakan Rakyat Indonesia. Jakarta: Dian Rakyat.
Purwadi, d. (2009). Sri Susuhunan Paku Buwono $x$ Perjuangan, Jasa \& Pengabdiannya untuk Nusa Bangsa. Jakarta: Bangun Jasa.

Ricklefs. (1991). Sejarah Indonesia Modern. Yogyakarta: Gama Pres.

Soeratman, D. (2000). Kehidupan Dunia Keeraton Surakarta. Yogyakarta: Yayasan untuk Indonesia.

Yatim, B. (1999). Soekarno, Islam, dan Nasionalisme. Jakarta: Logos Wacana IImu. 